\title{
PENGEMBANGAN MODEL GERAK DAN LAGU BERBASIS BUDAYA LAMPUNG UNTUK GURU PAUD DI BANDAR LAMPUNG
}

\author{
Siti Kurniasih, S.A.B., M.Pd \\ STKIP Al Islam Tunas Bangsa \\ s.kurniasih0@gmail.com \\ Yulistyas Dwi Asmira, M.Pd \\ STKIP Al Islam Tunas Bangsa \\ Yulis0789@gmail.com \\ Prisma Tejapermana, S.Sn., M.Pd \\ STKIP Al Islam Tunas Bangsa \\ prismatejapermana@gmail.com
}

\begin{abstract}
The objective of this research is to produce learning model of movements and songs based on Lampung culture that can be used by kindergarten teacher to improve aspects of early child development. The respondents of this research are 30 kindergarten teachers in Bandar Lampung. The method used in the research is the research and development that developed by Borg and Gall. The development of the model that used in this study is ASSURE: 1)Analyze Learners' need, 2)State objectives, 3)Select instructional methods, media and material, 4)Utilize media and material, 5)Require learner participation dan 6) Evaluate and revise. The technique of analysis data is using descriptive and qualitative. The result of research shows that the improvement of teachers' ability in developing the learning activity with movements and songs based on Lampung culture has the influence for children development aspect. The results of this study obtained a model product of learning movements and songs based on Lampung culture in the form of guidebooks and learning programs.
\end{abstract}

Keywords: Movements and Songs, Lampung Culture, Early Childhood, Kindergarten

\begin{abstract}
Abstrak: Tujuan dari penelitian ini adalah untuk menghasilkan model pembelajaran gerak dan lagu berbasis budaya Lampung yang dapat digunakan guru PAUD untuk meningkatkan aspek-aspek perkembangan anak usia dini. Responden penelitian ini adalah 30 guru PAUD di Bandar Lampung Metode yang digunakan dalam penelitian ini adalah penelitian dan pengembangan yang dikembangkan oleh Borg dan Gall. Pengembangan model yang digunakan dalam penelitian ini menggunakan ASSURE: 1) Menganalisis kebutuhan, 2) Tujuan pembelajaran, 3) Memilih metode pembelajaran, media dan materi, 4) Memanfaatkan media dan materi, 5) Memerlukan partisipasi peserta didik, dan 6) Mengevaluasi dan merevisi. Teknik analisis data dengan menggunakan deskripsi dan kualitatif. Hasil penelitian menunjukkan adanya peningkatan kemampuan guru dalam mengembangkan kegiatan pembelajaran dengan gerak dan lagu berbasis budaya Lampung yang sangat berpengaruh terhadap aspek-aspek perkembangan anak. Hasil penelitian ini diperoleh suatu produk model pembelajaran gerak dan lagu berbasis budaya Lampung berupa buku panduan dan program pembelajaran.
\end{abstract}

Kata Kunci: Gerak dan Lagu, Budaya Lampung, Anak Usia Dini, PAUD 


\section{PENDAHULUAN}

Pendidikan Anak Usia Dini (PAUD) merupakan salah satu bentuk penyelenggara pendidikan yang memiliki peran penting karena pendidikan merupakan dasar pembentukan kepribadian manusia untuk mengembangkan moral/nilai-nilai agama, bahasa, kognitif/kecerdasan, fisik-motorik, sosial-emosional, dan seni. Pembentukan kepribadian pada anak usia dini menjadi harapan baru untuk menghasilkan penerus bangsa yang berkualitas dan berkarakter. Dalam mewujudkan harapan tersebut, bentuk pendidikan anak usia dini harus dilaksanakan sesuai dengan kebutuhan dan tahapan perkembangan anak yang memiliki karakteristik berbeda satu sama lain. Pendidikan sejak dini merupakan salah satu cara untuk membantu pertumbuhan dan perkembangan anak, seperti yang tercantum dalam Undang-Undang Nomor 20 Tahun 2003 tentang Sistem Pendidikan Nasional menyatakan bahwa:

Pendidikan Anak Usia Dini (PAUD) adalah suatu upaya pembinaan yang ditunjukkan kepada anak sejak lahir sampai dengan usia enam tahun yang dilakukan melalui pemberian rangsangan pendidikan untuk membantu pertumbuhan dan perkembangan jasmani dan rohani agar anak memiliki kesiapan dalam memasuki pendidikan lebih lanjut.

Pemaparan tersebut memberikan makna bahwa pendidikan anak usia dini ditujukan untuk membantu orang tua dalam mengembangkan berbagai aspek perkembangan anak termasuk di dalamnya yaitu aspek perkembangan sosial-emosional, seni, fisik-motorik, bahasa, kognitif, dan moral-nilai agama moral/nilai-nilai agama, bahasa, kognitif/kecerdasan, fisikmotorik, sosial-emosional, dan seni. Optimalisasi seluruh potensi anak dapat berkembang menjadi lebih baik apabila mampu untuk menciptakan pembelajaran yang menyenangkan bagi anak. Berdasarkan hasil observasi dan dokumentasi, PAUD di kota Bandar Lampung memerlukan suatu model pembelajaran yang dapat merangsang perkembangan anak dan dapat melestarikan budaya Lampung. Hal ini terlihat pada proses pembelajaran, pembelajaran di kelas lebih banyak menggunakan metode bercerita, masih kurangnya aktivitas menggunakan gerakan tubuh, belum adanya kegiatan untuk melestarikan budaya Lampung, serta pembelajaran yang kurang kreatif sehingga anak cenderung bosan. Dari hasil wawancara beberapa guru juga menyimpulkan bahwa hal tersebut terjadi karena kurangnya contoh model pembelajaran yang dapat dilakukan guru, dan guru kurang mengikuti pelatihan-pelatihan yang sebenarnya dapat membantu guru untuk merancang kegiatan pembelajaran.

Aspek perkembangan motorik, sosial, dan seni anak yang terlihat kurang berkembang seharusnya dapat diatasi dengan membuat model pembelajaran yang menyenangkan. Selain itu, dinamika kehidupan juga mengalami perubahan yaitu anak-anak yang hidup di perkotaan mempunyai cara belajar dan bermain yang berbeda pula, mereka terbiasa menggunakan alat bermain yang lebih canggih atau maju sehingga kerap hilangnya pelestarian budaya Lampung. Pada kehidupan yang modern dan canggih ini, kehadiran identitas baru dan hilangnya identitas lama adalah risiko yang harus dipikul bersama. Oleh sebab itu, model pembelajaran yang dapat melestarikan kebudayaan Lampung perlu dikenalkan sejak usia dini.

Pembelajaran yang menyenangkan dan disukai anak dengan kegiatan berupa 
gerak dan lagu. Barlin seperti dikutip Mutiah (2012: 169) dalam penelitiannya mengungkapkan bahwa pengalaman dalam gerak mengajari anak untuk bersabar, menunggu teman lain melakukan latihan, tidak mengganggu, tidak menertawakan atau ribut, mengajari anak bertanggung jawab dalam kelompok, bekerja sama dengan teman, menstimulasi kesensitifan anak, mengembangkan perasaan disiplin. Menurut Bisono dalam Latif et al. (2014: 232) bahwa otak kanan merupakan tempat atau kemampuan imajinasi, Kreatifitas, estetika, dan inovasi. Sehingga tidak mengherankan jika banyak orang yang mengatakan bahwa kesuksesan seseorang sangat ditentukan oleh otak kanannya. Sebab otak kanan akan memberikan loncatan yang sangat tinggi daripada biasanya. Oleh sebab itu, stimulasi yang dapat mengembangkan aspek-aspek perkembangan anak, dan melestarikan budaya Lampung untuk anak usia dini yaitu dengan membuat model pembelajaran "gerak dan lagu berbasis budaya Lampung".

\section{Gerak dan Lagu}

Pembelajaran bagi anak usia dini harus disesuaikan dengan tahapan perkembangan dan usia anak karena akan bermanfaat bagi mereka hingga dewasa. Pembelajaran yang menyenangkan dengan proses yang tidak membosankan dapat dilaksanakan dengan menyediakan kegiatan yang anak sukai. Proses pembelajaran yang menyenangkan dan disukai bagi anak yaitu dengan gerak dan lagu. Soedarsono dalam Pekerti (2013: 5.3) menjelaskan bahwa desakan perasaan manusia tentang "sesuatu" yang disalurkan melalui gerak-gerak ritmis yang indah. Suryodiningrat seperti dikutip Artika (1990: 3) juga mengutarakan bahwa tari adalah gerak-gerak dari seluruh bagian tubuh manusia yang disusun selaras dengan irama musik serta mempunyai maksud tertentu.

Kegiatan gerakan kreatif yaitu melatih anak-anak menggerakkan kaki dan tubuh mereka ikuti irama yang diciptakan dengan tangan, melatih anak-anak bertepuk tangan ikuti irama. Atau gunakan lagu tradisional untuk berlatih bertepuk tangan ikuti irama yang berbeda (Beaty, 2013: 409). Gerak yang kreatif adalah gerakan yang ditampilkan secara menarik dengan menyesuaikan alunan lagu dan musik. Terlepas dari itu gerakan tari untuk anak usia dini sebaiknya yang mudah dan tidak terlalu variasi, menyenangkan dan dalam kondisi tertentu gerakan tari bersifat alami (Kemendikbud, 2013: 583). Brewer mengutarakan bahwa movement experiences should be planned to include both creative and more structure movements. Creative movement activities are those in which children interpret instructions in their own ways; their movements may not necessarily match the beat of the music (Brewer, 2007:436). Berdasarkan dari beberapa definisi gerak tersebut, maka disimpulkan bahwa gerak kreatif adalah gerakan yang telah disusun dengan indah oleh anggota tubuh manusia dan sesuai dengan lagu penggiringnya serta memiliki fungsi dan kegunaan.

Lagu sebagai penggiring gerakan kreasi anak. Menurut Pamadhi (2009: 6.41) bahwa hal-hal yang menjadi pertimbangan dalam mengembangkan pola ritmik dan pemilihan instrumen musik iringan suatu lagu anak adalah mencari ritme melodi lagu dan pola gerakan harmoni/akornya. Irama merupakan bagian alami dari kita semua. Sebagain besar anak telah bertepuk tangan sejak bayi. Musik adalah kombinasi suara dan atau instrumen untuk mengkreasikan melodi dan bunyi teratur. Kegiatan bermain musik dapat dilakukan dengan gerak dan lagu. Sebelum anak diajarkan biasanya anak akan diajak 
bergerak bebas mengikuti irama musik kemudian mereka mulai dikenalkan dengan kegiatan gerak tari yang berpola dan menggunakan beberapa formasi (Kemendikbud, 2013: 585). Brewer juga mengungkapkan bahwa music like the visual arts, is a basic way of learning, experiencing, and communicating. All children deserve a rich musical environment in which to learn to sing, to play music, to move, and to listen. Music is also a valuable control for helping children gain content knowledge and make sense of their experience (Brewer, 2007: 428-429).

Musik adalah suara yang disusun demikian rupa sehingga mengandung irama, lagu, dan keharmonisan terutama suara yang dihasilkan dari alat-alat yang dapat menghasilkan bunyi (Latif et al., 2014: 229). Musik yang mengandung lagu-lagu juga dapat membantu anak merasa bertenaga, percaya diri, mengurangi kesedihan, menghapus kemarahan, melepaskan stress serta mengembangkan kecerdasan musikal anak. Berdasarkan pendapat para ahli tersebut maka dapat disimpulkan bahwa gerak dan lagu adalah suatu kegiatan yang menyenangkan bagi anak yang dilakukan melalui gerakan tubuh dan merespon suara yang dihasilkan dari alat-alat yang dapat menghasilkan bunyi untuk mengembangkan aspek-aspek perkembangan anak.

\section{Budaya Lampung}

Pada kehidupan yang modern dan canggih ini, kehadiran identitas baru dan hilangnya identitas lama adalah risiko yang harus dipikul bersama. Oleh sebab itu, membangun dan melestarikan kebudayaan Lampung merupakan kewajiban semua lapisan masyarakat Lampung. Budaya adalah suatu cara hidup yang berkembang dan dimiliki bersama oleh sebuah kelompok orang dan diwariskan dari generasi ke generasi. Bachtiar dalam Esten (1999: 22) sebagai sistem budaya, tradisi merupakan suatu sistem yang menyeluruh, yang terdiri dari cara aspek yang pemberian arti terhadap laku ujaran, laku ritual, dan berbagai jenis laku lainnya dari manusia atau sejumlah manusia yang melakukan tindakan satu dengan yang lain. Sebagaimana sebuah daerah, Lampung memiliki beraneka ragam jenis musik, mulai dari jenis tradisional hingga modern (musik modern yang mengadopsi kebudayaan musik global).

Pendidikan tidak terlepas dari kebudayaan, tanpa kebudayaan tidak mungkin lahir suatu kepribadian. Oleh sebab itu proses pendidikan tidak bisa lain dari proses pembudayaan. Kebudayaan daerah harus diganti dan dikembangkan sebagai nilai-nilai pendidikan formal, non formal, maupun informal. Pengembangan kebudayaan daerah tidak akan berarti melunturkan perkembangan nasionalisme, bahkan akan memperkuat kepribadian seseorang oleh karena dia dibentuk oleh nilai-nilai budaya yang konkret. Sejalan dengan itu pendidikan perlu memperhatikan bahwa anak-anak kita adalah anak dari masyarakat Indonesia dan oleh sebab itu wajib mengenal dan mengembangkan kebudayaan nasional melalui kebudayaan daerahnya (Tilaar, 2004: 93). Lembaga-lembaga pendidikan merupakan pranata sosial dari suatu masyarakat yang berbudaya. Dengan demikian fungsi lembaga tersebut tidak lain ialah memelihara, mengembangkan, dan mewujudkan nilai-nilai budaya yang dimiliki oleh masyarakat pemilihnya. Lembaga-lembaga pendidikan yaitu keluarga, lembaga-lembaga pendidikan formal dan non-formal, yang diselenggarakan oleh masyarakat semuanya merupakan pranata sosial yang menjadi tumpuan kesinambungan 
hidup bersama yang diikat oleh nilai-nilai kebudayaan (Tilaar, 2004: 210). Dengan demikian, lembaga pendidikan memiliki peran penting untuk mengembangkan kebudayaan dari setiap daerah.

Model pembelajaran berbasis budaya lokal tetap berorientasi kepada tugas perkembangan anak, dikembangkan didasarkan kepada karakteristik wilayah dan sesuai tata kehidupan masyarakat setempat, dan memanfaatkan seoptimal mungkin sarana, media, alat permainan yang ada di daerah masing-masing untuk kepentingan pembelajaran bagi anak didik. Alat permainan tradisional, kesenian daerah, nyanyian perlu digali dan dikembangkan sebagai kekhasan daerah yang perlu dilestarikan (Masnipal, 2013: 175). Oleh sebab itu, proses pembelajaran selain bertujuan untuk meningkatkan perkembangan anak, juga dapat melestarikan budaya dengan mengadopsi budaya daerah melalui pembelajaran yang menyenangkan dan sesuai dengan usia tahapan perkembangan anak.

\section{Karakteristik Gerak dan Lagu Anak Usia Dini}

Pembelajaran gerak dan lagu untuk anak usia dini memiliki karakteristik. Pada umumnya anak-anak selalu menyenangi apa yang pernah dilihatnya secara tidak disadari atau tidak dengan spontan menirukan sesuai dengan apa yang pernah dilihatnya. Bentuk gerak yang sesuai dengan karakteristik gerak anak usia, pada umumnya gerak-gerak yang dilakukannya tidaklah sulit dan sederhana sekali. Dalam menari anak usia dini biasanya menyenangi musik iringan yang menggambarkan kesenangan atau kegembiraan.Tempo yang digunakan dikategorikan Andante, Giocoso, Moderato kadangkadang Alleggro tetapi sering digunakan tempo Andante, Giocoso, dan Moderato (Latif et al., 2014: 231). Gerakan anak usia dini paling tidak memiliki sifat kegembiraan atau kesenangan, geraknya lincah dan sederhana, iringannya pun mudah dipahami. Gilbert dalam Brewer (2007: 431) mengutarakan bahwa The following points to consider when choosing songs to teach:

1)The song shoukd appeal to the children, 2) The song should not be too long and in general, the younger the child the greater the need for repetition and for a predictable pattern within each verse, 3) Songs with a chourus encourage even shy children to join in, 4) Songs which lend themselves to movement often have greater potential with young children, 5) Avoid tunes with very high notes or difficult leaps, 6) Choose songs with word that the children understand.

Sependapat dengan Gilbert, Menurut Andersen seperti dikutip Latif (2014: 230) menyatakan bahwa bagi anak PAUD karakteristik kemampuannya sebagai berikut:

1) Suara bercirikan ringan dan tinggi (hanya beberapa saja yang rendah suaranya),

2) Rata-rata belum bisa bernyanyi dengan nada yang tepat, 3) Gemar menyanyikan kalimat pendek (dalam bentuk melodi) dan suka bernyanyi sendiri, 4) Mulai memahami tinggi dan rendah suara, 5) Batas suara umumnya satu oktaf, 6) Polapola nada sederhana, 7) Lagu yang dinyanyikan tentang hewan dan tumbuhan, persahabatan, lingkungan, dan keagungan Tuhan. 
Berdasarkan pendapat beberapa ahli tersebut maka disimpulkan bahwa karakteristik gerak dan lagu untuk anak usia dini yaitu bentuk gerak pada umumnya gerak-gerak yang dilakukannya tidaklah sulit dan sederhana sekali, musik iringan yang menggambarkan kesenangan atau kegembiraan dengan lagu-lagu anak yang mudah diingat.

\section{METODOLOGI PENELITIAN}

Penelitian ini menggunakan metode penelitian dan pengembangan (Research and Development). Desain penelitian pengembangan berdasarkan tahapan-tahapan penelitian pengembangan Borg dan Gall (1983: 775). Tahapan-tahapan penelitian tersebut diuraikan sebagai berikut:

a. Melakukan penelitian/studi pendahuluan untuk mengumpulkan informasi (kajian pustaka dan pengamatan kelas), identifikasi permasalahan yang dijumpai dalam pembelajaran, dan merangkum permasalahan.

b. Melakukan perencanaan. Aspek yang penting dalam perencanaan adalah pernyataan tujuan yang harus dicapai pada produk yang akan dikembangkan.

c. Mengembangkan jenis/bentuk produk awal meliputi: penyiapan materi pembelajaran, penyusunan model gerak dan lagu berbasis budaya Lampung, dan perangkat evaluasi.

d. Melakukan uji coba tahap awal, yaitu evaluasi pakar bidang desain pembelajaran, pakar konten, dan uji terbatas.

e. Melakukan revisi terhadap produk utama, berdasarkan masukan dan saran-saran dari hasil uji lapangan awal.

f. Melakukan uji lapangan, digunakan untuk mendapatkan evaluasi atas produk. Angket dibuat untuk mendapatkan umpan balik dari anak yang menjadi sampel penelitian.

g. Melakukan revisi terhadap produk operasional, berdasarkan masukan dan saran-saran hasil uji lapangan dan praktisi pendidikan.

h. Uji coba operasional.

i. Perbaikan produk akhir.

j. Diseminasi.

Lokasi penelitian ini dilaksanakan di Bandar Lampung. Penelitian dilakukan pada Guru PAUD di Kota Bandar Lampung yang berjumlah 30 guru PAUD. Peneliti akan mengamati Kreatifitas guru PAUD untuk mengembangkan pembelajaran yang akan memengaruhi perkembangan atau potensi yang dimiliki anak dengan membuat model pembelajaran yaitu model gerak dan lagu berbasis budaya Lampung. Perubah atau yang diamati tentang peningkatan Kreatifitas guru dalm pembelajaran dan perkambangan anak dengan model gerak dan lagu berbasis budaya Lampung yang dikembangkan dengan menggunakan angket untuk mengetahui persepsi guru, kepsek, dan orang tua terkait dengan produk yang dirancang (model gerak dan lagu berbasis budaya Lampung).

Model yang digunakan dalam penelitian ini menggunakan ASSURE, dengan rancangan model sebagai berikut:

1. Analisis Kebutuhan dan Identifikasi Sumber Daya untuk Memenuhi Kebutuhan

2. Perencanaan 
3. Mengembangkan Produk Awal

4. Uji Coba Terbatas

5. Revisi Produk

6. Uji Lapangan

7. Penyempurnaan Produk

\section{Teknik Pengumpulan Data}

Teknik pengumpulan data dilakukan dengan cara menyebarkan angket. Angket diberikan kepada guru, kepala sekolah, dan orangtua untuk memperoleh data analisis kebutuhan anak terhadap model gerak dan lagu berbasis budaya Lampung yang akan dikembangkan oleh peneliti. Angket berikutnya diberikan kepada tim ahli (expert judgement) untuk mengevaluasi model yang dikembangkan dan angket terakhir adalah angket yang digunakan untuk mendapatkan data mengenai kemenarikan model gerak dan lagu berbasis budaya Lampung, kemudahan mengaplikasikan model gerak dan lagu berbasis budaya Lampung, dan peran model pembelajaran bagi guru untuk perkembangan sosial-emosional, fisik-motorik, dan seni anak.

\section{Teknik Analisis Data}

Data kualitatif merupakan data yang menunjukkan kualitas proses, peristiwa, keadaaan dan lainnya alam bentuk pernyataan. Data-data yang diperoleh dilakukan analisis data dengan melihat tahapan menurut Milles dan Huberman (1989: 21) yang mengemukakan bahwa analisis kualitatif menggunakan teknik yang terdiri dari: data reduction, data display, conclusing drawing/verification.

\section{HASIL DAN PEMBAHASAN}

Hasil penelitian dan pembahasan menunjukkan bahwa guru dapat membuat model pembelajaran gerak dan lagu berbasis budaya Lampung dalam mengembangkan aspek-aspek perkembangan anak sesuai tahapan dan usia anak TK B. Pada proses pengembangan model pembelajaran gerak dan lagu, model pengembangan yang digunakan adalah tipe ASSURE. Tipe ini dipilih sebagai langkah untuk mensinkronkan antara bahan ajar yang digunakan, metode pembelajaran dan karakteristik objek belajar. Proses pengembangan bahan ajar tersebut dilakukan berdasarkan proses: 1) Analyze Learner, 2)State objectives, 3) Select instructional methods, media and material, 4)Utilize media and material, 5) Require learner participation, dan 6) Evaluate and revise.

\section{Analyze Learner}

Hasil analisis kemampuan guru dalam menciptakan gerak dan lagu yang terkumpul melalui data menunjukkan bahwa guru PAUD belum memiliki kompetensi spesifik atau khusus yang dapat menunjang pembelajaran, anak didik memerlukan model pembelajaran 
gerak dan lagu untuk meningkatkan aspek-aspek perkembangan anak. Berdasarkan analisis karakteristik pembelajar maka dibutuhkan model pembelajaran yang tidak harus mahal, tetapi sesuai dengan usia dan tahapan perkembangan anak sehingga anak didik mudah mempelajari materi pembelajaran.

\section{State Objectives}

Langkah kedua ini dilakukan dengan merumuskan tujuan pembelajaran. Menyusun Rencana Kegiatan Mingguan (RKM) dan Rencana Kegiatan Harian (RKH).

\section{Utilize, Require, learner}

Tahap ketiga model ASSURE, Select methods, media and material yaitu tahap pemilihan metode, media dan bahan. Pada langkah ini yang dihasilkan adalah Rencana Kegiatan Harian (RKH) yang berisi uraian indikator, kegiatan pembelajaran, nilai karakter, metode, alat/sumber belajar, penilaian perkembangan anak. Langkah keempat dan kelima adalah dua langkah yang saling berkaitan yaitu memanfaatkan pembelajaran gerak dan lagu dan melibatkan anak didik dalam kegiatan pembelajaran. Langkah keenam ASSURE (evaluate and revise) yaitu tahap mengevaluasi dan merevisi model pembelajaran gerak dan lagu. Tahap ini adalah validasi model pembelajaran gerak dan lagu untuk menilai model layak atau tidak dikembangkan.

\section{Peningkatan Kemampuan Guru dalam Pengembangan Model Gerak dan Lagu Berbasis Budaya lampung}

Hasil analisis deskriptif peningkatan kemampuan guru setelah dilakukan pelatihan dan pengembangan model dari delapan aspek pengukuran yaitu

1) Membuat suatu karya gerak dan lagu berbasis budaya Lampung

2) Memperkirakan waktu dalam menyelesaikan karyanya

3) Menggunakan suatu objek menjadi berbagai bentuk dan fungsi

4) Menghasilkan model gerak dan lagu berbasis budaya Lampung yang dapat meningkatkan aspek-aspek perkembangan anak

5) Menghasilkan karya yang sesuai dengan usia anak

6) Membuat karya yang sesuai dengan tahapan perkembangan anak

7) Memberikan ide masukan kepada guru lain

8) Menjalin komunikasi yang efektif dalam menciptakan suasana pembelajaran yang menyenangkan

Hasil analisis deskriptif peningkatan kemampuan guru setelah dilakukan pelatihan disajikan pada tabel-tabel di bawah ini:

Tabel 1 Perbandingan Hasil Pengamatan Awal (I) dan Pengamatan Akhir (II) Kemampuan Guru PAUD

\begin{tabular}{|c|c|c|c|c|c|c|c|c|c|}
\hline \multirow{3}{*}{ No } & \multirow{2}{*}{ Aspek } & \multicolumn{6}{|c|}{ Pengamatan Kemampuan Guru PAUD } \\
\cline { 3 - 9 } & & \multicolumn{2}{|c|}{ Baik Sekali } & \multicolumn{2}{|c|}{ Baik } & \multicolumn{2}{c|}{ Cukup } & \multicolumn{2}{c|}{ Kurang Baik } \\
\cline { 3 - 9 } & & I (\%) & II (\%) & I (\%) & II (\%) & I (\%) & II (\%) & I (\%) & II (\%) \\
\hline 1 & 1 & 0 & 10,00 & 10,00 & 26,67 & 43,33 & 46,67 & 46,67 & 16,67 \\
\hline
\end{tabular}




\begin{tabular}{|c|c|c|c|c|c|c|c|c|c|}
\hline 2 & 2 & 0 & 13,33 & 16,67 & 33,33 & 33,33 & 33,33 & 50,00 & 20,00 \\
\hline 3 & 3 & 0 & 13,33 & 23,33 & 43,33 & 36,67 & 30,00 & 40,00 & 13,33 \\
\hline 4 & 4 & 0 & 10,00 & 13,33 & 26,67 & 40,00 & 46,67 & 46,67 & 16,67 \\
\hline 5 & 5 & 0 & 13,33 & 20,00 & 33,33 & 33,33 & 40,00 & 46,67 & 13,33 \\
\hline 6 & 6 & 0 & 10,00 & 10,00 & 33,33 & 56,67 & 46,67 & 33,33 & 10,00 \\
\hline 7 & 7 & 0 & 13,33 & 16,67 & 40,00 & 43,33 & 36,67 & 40,00 & 10,00 \\
\hline 8 & 8 & 0 & 13,33 & 13,33 & 46,67 & 63,33 & 36,67 & 23,33 & 3,33 \\
\hline \multicolumn{2}{|c|}{ Rata-rata } & 0 & 12,08 & 15,42 & 35,42 & 43,75 & 39,58 & 40,83 & 12,92 \\
\hline
\end{tabular}

Berdasarkan tabel di atas dapat dijelaskan bahwa, setelah guru selesai mengikuti pelatihan kegiatan pembelajaran secara umum diperoleh penguasaan model pembelajaran gerak dan lagu berbasis budaya Lampung yang meningkat dari kategori kurang baik menjadi cukup baik, baik, dan baik sekali. Sebelum pelatihan guru, terlebih dahulu dilakukannya observasi dan wawancara mengenai kemampuan guru mengelola kegiatan pembelajaran untuk memperoleh informasi kondisi awal yang berkaitan dengan kebutuhan dan potensi dari guru untuk mengembangkan aspek perkembangan anak. Pada akhir pelatihan juga dilakukannya pengamatan, wawancara, dan praktek langsung yang dilakukan guru, serta anak-anak yang mengikuti kegiatan gerak dan lagu berbasis budaya Lampung. Pengamatan, wawancara, dan praktek langsung juga untuk memperoleh informasi tentang perubahan kondisi peserta, tanggapan mereka, dan sekaligus untuk mengetahui keberhasilan penyelenggaraan penelitian. Berdasarkan hasil pengamatan awal yang dibandingkan dengan pengamatan akhir diperoleh data seperti yang termuat pada tabel di atas. Data tersebut memperlihatkan seberapa jauh perbedaan kondisi akhir kemampuan guru dalam melaksanakan kegiatan pembelajaran jika dibandingkan dengan kondisi awal sebelum mereka mengikuti pelatihan.

Hasil penelitian yang diperoleh dapat dijelaskan bahwa kondisi awal guru mengenai kemampuan guru dalam menciptakan suatu kegiatan pembelajaran yang menarik dan menyenangkan bagi anak usia dini. Kemampuan guru dalam meningkatkan aspek-aspek perkembangan anak yang kaitannya dengan pelatihan dalam menciptakan model gerak dan lagu berbasis budaya Lampung secara umum diperoleh data rata-rata penguasaan guru menunjukkan bahwa untuk kategori baik sekali sebesar $0 \%$ atau belum ada kemampuan guru yang menunjukkan baik sekali dalam membuat kegiatan pembelajaran gerak dan lagu berbasis budaya Lampung, 15,42\% guru yang memperlihatkan kategori baik, 43,75\% dalam kategori cukup, dan 40,83\% dalam kategori kurang baik. Setelah selesai pelatihan, secara umum kondisi mereka diperoleh peningkatan. Pada akhir penelitian menunjukkan hasil $12,08 \%$ guru masuk pada kategori baik sekali, $35,42 \%$ pada kategori baik yang mengalami peningkatan $20 \%$ dari awal pengamatan. Dan untuk kategori cukup mengalami penurunan sebesar $4,17 \%$ dikarenakan beberapa guru yang awalnya masuk kategori cukup meningkat ke kategori baik dan baik sekali. Untuk guru yang masuk ke kategori kurang baik dalam membuat suatu pembelajaran gerak dan lagu berbasis budaya Lampung mengalami penurunan sebesar $27,91 \%$ yang pada awal pengamatan menunjukkan hasil sebesar 40,83\% dan akhir pengamatan sebesar $12,92 \%$, dikarenakan beberapa guru yang awalnya masuk kategori kurang baik meningkat ke kategori cukup, dan baik. Proses pengembangan bahan ajar dengan model pembelajaran gerak dan lagu untuk meningkatkan aspek-aspek perkembangan anak dilakukan berdasarkan proses sebagai berikut: 


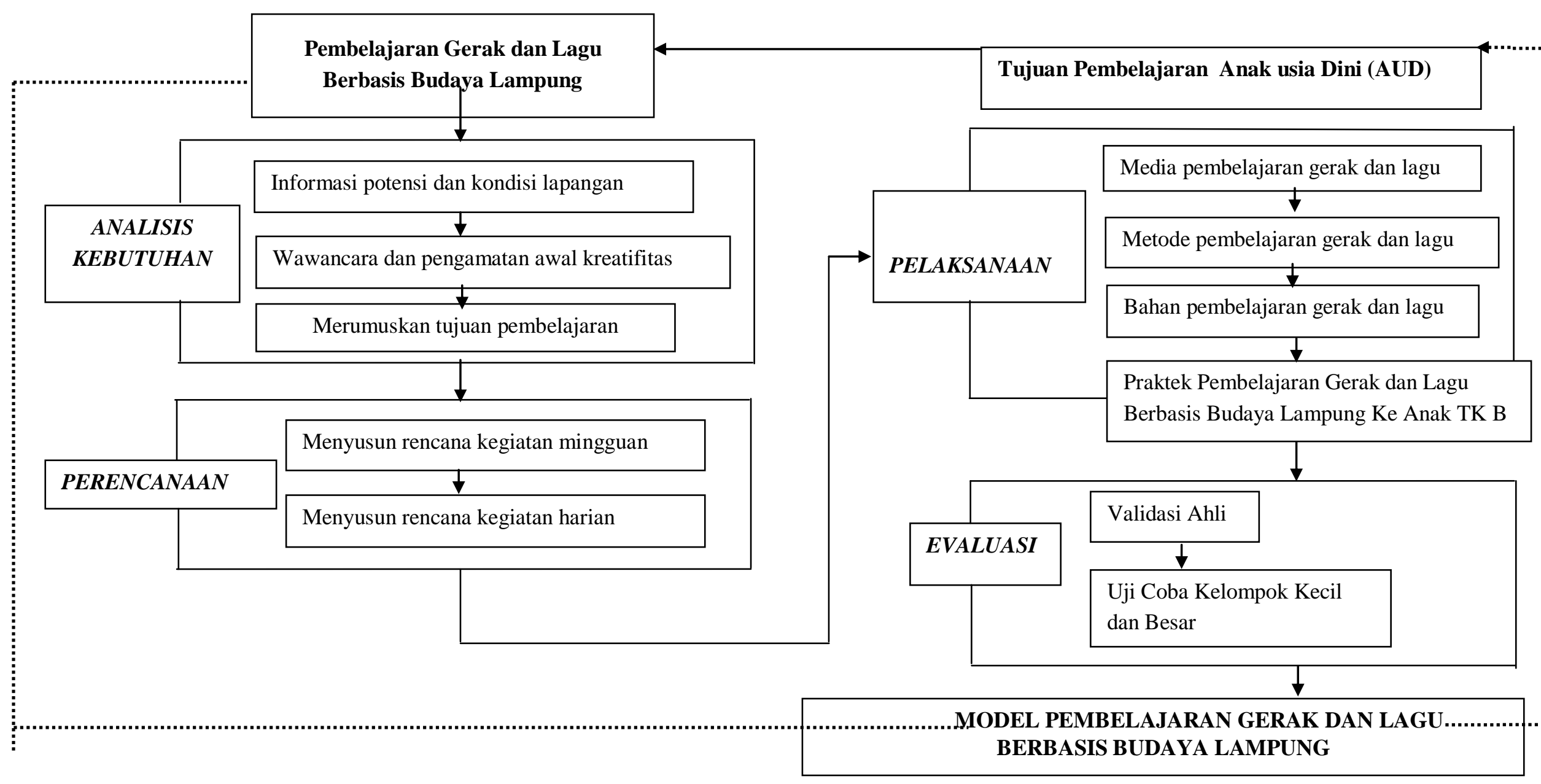


Pendidikan anak usia dini ditujukan untuk meningkatkan aspek-aspek perkembangan anak yang sangat berkaitan dengan kemampuan guru dalam mengelola pembelajaran. Kreatifitas guru PAUD sangat diperlukan guna memperkaya kegiatan pembelajaran. Model pembelajaran yang menyenangkan dan sesuai dengan tahapan usia anak yaitu dengan gerak dan lagu. Gerak dan lagu adalah suatu kegiatan yang menyenangkan bagi anak yang dilakukan melalui gerakan tubuh dan merespon suara yang dihasilkan dari alat-alat yang dapat menghasilkan bunyi untuk mengembangkan kecerdasan anak. Gerak dan lagu dikemas dengan budaya lampung yang dapat melestarikan budaya Lampung. Tahapan dalam pengembangan model pembelajaran gerak dan lagu yaitu:

1) Guru membuat perencanaan pembelajaran

2) Guru mencari berbagai sumber belajar yang disesuaikan dengan tema

3) Materi yang akan diberikan harus melihat usia dan tahapan perkembangan anak

4) Guru merancang gerakan dan menentukan irama/lagu yang menyenangkan dan memberikan semangat kepada anak untuk belajar

5) Guru menyediakan sarana dan media yang akan diperlukan.

Kegiatan gerakan kreatif diberikan guru dengan gerakan yang sesuai dengan usia anak, selanjutnya melatih anak-anak menggerakkan kaki dan tubuh mereka diikuti irama. Gerakan yang dilakukannya tidaklah sulit dan sederhana sekali, musik iringan yang menggambarkan kesenangan atau kegembiraan anak untuk bergerak dan memberikan contoh-contoh gerakan. Strategi pembelajaran melalui gerak dan lagu ini menggunakan media yaitu gambar, video, dan musik yang sesuai dengan ritme dan karakteristik anak usia dini. Gerak dan lagu merupakan kegiatan yang melibatkan seluruh tubuh dan panca indera anak. Proses pembelajaran gerak dan lagu berbasis budaya lampung dapat membangun dan melestarikan kebudayaan Lampung yang merupakan kewajiban semua lapisan masyarakat Lampung.

Model pembelajaran PAUD berbasis budaya lokal tetap berorientasi kepada tugas perkembangan anak, dikembangkan didasarkan kepada karakteristik budaya Lampung. Oleh sebab itu, proses pembelajaran selain bertujuan untuk meningkatkan perkembangan anak, juga dapat melestarikan budaya dengan mengadopsi budaya daerah melalui pembelajaran yang menyenangkan dan sesuai dengan usia tahapan perkembangan anak.

Penelitian ini menghasilkan prototype model gerak dan lagu berbasis budaya Lampung yang dapat digunakan guru PAUD untuk meningkatkan aspek perkembangan sosial-emosional, fisik-motorik, dan seni anak. Aspek-aspek perkembangan motorik, sosial, dan seni anak yang terlihat kurang berkembang dapat diatasi dengan membuat model pembelajaran gerak dan lagu yang menyenangkan. Model pembelajaran gerak dan lagu berbasis budaya Lampung ini dapat meningkatkan kemampuan guru dalam mengelola pembelajaran. Kemampuan guru dalam mengelola pembelajaran memiliki dampak positif bagi peningkatan aspek-aspek perkembangan anak yaitu sosial-emosional, fisik-motorik, dan seni. Bermain gerak dan lagu ini juga membangkitkan dan membebaskan anak untuk melakukan kegiatan berolah seni sesuai dengan kemampuannya sehingga menghasilkan halhal yang baru. Kegiatan gerak dan lagu juga untuk membentuk dasar-dasar akan kesadaran sosial anak. Pembelajaran gerak dan lagu berbasis budaya Lampung berkaitan dengan kemampuan anak untuk membina interaksi dan bekerja sama dengan anak lain, yang membutuhkan penyesuaian diri (adaptasi) dalam membangun keharmonisan saat 
melaksanakan kegiatan gerak dan lagu. Hasil penelitian ini juga memperlihatkan hasil yang sama dengan penelitian Yetty et al (2015) yang menyatakan bahwa bermain tari kreasi yaitu gerak kreatif yang diiringi dengan musik kemudian anak menari bersama-sama dapat meningkatkan kecerdasan interpersonal anak. Oleh sebab itu, dengan gerak dan lagu anak berbasis budaya Lampung juga dapat melatih diri dalam berhubungan sosial dengan orang lain.

Gerak dan lagu berbasis budaya Lampung juga mengembangkan keterampilan anak lainnya, seperti anak dapat mengontrol gerak motorik kasar dan menguasai motorik halus. Paspiani (2015) dalam penelitiannya juga memberikan kesimpulan bahwa perkembangan motorik kasar anak akan berkembang dengan baik apabila diberikan stimulus yang mampu mendorong anak untuk bergerak, salah satu cara untuk mengembangkan motorik kasar adalah dengan kegiatan latihan gerak dan lagu.

Gerak dan lagu berbasis budaya Lampung juga mengembangkan kognitif anak yang membantu anak membangun konsep dan pengetahuan dari tema pembelajaran. Anak dapat mengembangkan kemampuan berpikir dalam memahami pola gerak, hitungan, dan penalaran. Pamadhi (2009: 3.3) menyatakan fungsi pendidikan dalam kaitannya dengan tahapan-tahapan perkembangan (kognitif, personal, sosial, dan fisik) pada hakikatnya adalah mengoptimalkan perkembangan tersebut sesuai dengan tugas perkembangannya. Gerak dan lagu berbasis budaya Lampung juga berhubungan dalam ilmu bahasa pada sarana komunikasi untuk mengungkapkan apa yang dirasakan. Hasil penelitian ini juga menggambarkan hasil yang sama dengan penelitian Dewi (2016) yang menyatakan bahwa kemampuan berbahasa anak TK B dapat meningkat melalui penerapkan metode bermain peran melalui gerak dan lagu. Oleh sebab itu, gerak dan lagu berbasis budaya Lampung menyediakan ruang dan waktu bagi anak untuk berinteraksi dengan orang lain, mereka saling berbicara, mengeluarkan pendapat, dan menambah kosakata anak.

Model pembelajaran gerak dan lagu bagi anak merupakan salah satu upaya untuk mengembangkan bakat yang ada pada anak. Seni memiliki peran membantu kecerdasan siswa di bidang lain (Pamadhi, 2009: 9.23). Dalam seni tari misalnya kita mengenal adanya tiga elemen dasar untuk mempelajari yaitu wiraga, wirama, dan wirasa. Dari landasan itu guru dapat menstimulasi bakat atau kecerdasan anak di bidang lain. Oleh sebab itu, stimulasi yang dapat mengembangkan aspek-aspek perkembangan anak usia dini serta melestarikan budaya Lampung yaitu dengan membuat model pembelajaran "gerak dan lagu berbasis budaya lampung".

\section{KESIMPULAN}

Kesimpulan penelitian secara umum adalah dihasilkannya model gerak dan lagu berbasis budaya Lampung. Hasil penelitian menunjukkan adanya adanya peningkatan kemampuan guru dalam mengembangkan kegiatan pembelajaran dengan gerak dan lagu berbasis budaya Lampung yang sangat berpengaruh pada peningkatan aspek-aspek perkembangan anak. Hal tersebut ditunjukkan dari hasil analisis deskripsi yang menunjukkan adanya peningkatan dari proses pengembangan model gerak dan lagu berbasis budaya Lampung. Berdasarkan hasil pengamatan awal yang dibandingkan dengan pengamatan akhir diperoleh data yang menunjukkan bahwa adanya peningkatan kemampuan 
guru dalam mengembangkan suasana pembelajaran yang sesuai dengan usia dan tahapan perkembangan anak.

Kemampuan guru dalam meningkatkan aspek-aspek perkembangan anak yang kaitannya dengan pelatihan dalam menciptakan model gerak dan lagu berbasis budaya Lampung secara umum diperoleh data rata-rata penguasaan guru menunjukkan bahwa untuk kategori baik sekali sebesar $0 \%$ atau belum ada kemampuan guru yang menunjukkan baik sekali dalam membuat kegiatan pembelajaran gerak dan lagu berbasis budaya Lampung, $15,42 \%$ guru yang memperlihatkan kategori baik, 43,75\% dalam kategori cukup, dan 40,83\% dalam kategori kurang baik. Setelah selesai pelatihan, secara umum kondisi mereka diperoleh peningkatan. Pada akhir penelitian menunjukkan hasil 12,08\% guru masuk pada kategori baik sekali, 35,42\% pada kategori baik yang mengalami peningkatan $20 \%$ dari awal pengamatan. Dan untuk kategori cukup mengalami penurunan sebesar 4,17\% dikarenakan beberapa guru yang awalnya masuk kategori cukup meningkat ke kategori baik dan baik sekali. Untuk guru yang masuk ke kategori kurang baik dalam membuat suatu pembelajaran gerak dan lagu berbasis budaya Lampung mengalami penurunan sebesar $27,91 \%$ yang pada awal pengamatan menunjukkan hasil sebesar 40,83\% dan akhir pengamatan sebesar 12,92\%, dikarenakan beberapa guru yang awalnya masuk kategori kurang baik meningkat ke kategori cukup, dan baik.

Proses dalam mengelola kegiatan pembelajaran gerak dan lagu berbasis budaya Lampung memberikan kesempatan anak untuk mendapatkan pengalaman bermakna dan melakukan banyak interaksi dalam kegiatan pembelajaran. Proses gerak dan lagu melalui beberapa tahap yaitu kegiatan awal, kegiatan inti, dan kegiatan penutup. Strategi pembelajaran melalui gerak dan lagu ini menggunakan media yaitu gambar, video, dan musik yang sesuai dengan ritme dan karakteristik anak usia dini. Penyelenggaraan penelitian ini diperoleh hasil yang baik dalam meningkatkan kemampuan guru dalam model pembelajaran gerak dan lagu berbasis budaya Lampung yang juga berdampak positif bagi peningkatan aspek-aspek perkembangan anak usia dini.

\section{SARAN}

Berdasarkan kesimpulan yang telah dikemukakan sebelumnya, adapun saran yang bisa peneliti berikan adalah sebagai berikut: (a) Bagi guru diharapkan lebih banyak mencari informasi untuk mengembangkan Kreatifitas dalam kegiatan pembelajaran, memberikan kesempatan kepada anak untuk melakukan aktivitas yang bisa menstimulasi aspek-aspek perkembangan anak. (b) Bagi orangtua, diharapkan orangtua dapat memberikan stimulasi yang berkaitan dengan peningkatan aspek-aspek perkembangan anak di rumah kepada anak sebagai bentuk keberlanjutan program yang diberikan oleh guru disekolah. (c) Bagi peneliti lain, diharapkan lebih memperkaya kajian-kajian penelitian terkait peningkatan aspek-aspek perkembangan anak dengan menggunakan maupun menemukan metode yang tepat dan sesuai dengan usia anak.

\section{DAFTAR PUSTAKA}

Artika, I Ketut. 1990. Pendidikan Seni Tari. Singaraja: Depdikbud.

Beaty, Janice J. 2013. Observasi Perkembangan Anak Usia Dini. Jakarta: Kencana. 
Brewer, Jo Ann. 2007. Early Childhood Education Preschool Through Primary Grade.

Brog. W. R dan Gall, M. D. 1983. Education Reasearch Anintroduction. New York: Longman.

Dewi, L. P. K., Manuaba, I. B. S., Fo, M., \& Suadnyana, I. N. 2016. Penerapan Metode Bermain Peran Melalui Gerak dan Lagu Untuk Meningkakan Kemampuan Berbahasa Anak Kelompok B di TK Laksana Kumara Denpasar. Jurnal Pendidikan Anak Usia Dini, Vol 4 (1). https://ejournal.undiksha.ac.id/index.php/JJPAUD/article/view/6782 diakses 12 Juni 2017 Pukul 20:44 WIB

Esten, Mursal. 1999. Kajian Transformasi Budaya. Bandung: Angkasa.

Kemendikbud RI. 2013. Modul Pelatihan dan Latihan Profesi Guru Taman KanakKanak. Jakarta: BPSDMPK-PMP.

Latif, Mukhtar., et al. 2013. Orientasi Pendidikan Anak Usia Dini. Jakarta: Kencana.

Masnipal. 2013. Siap Menjadi Guru dan Pengelola PAUD Profesional. Jakarta: Media Group.

Miles, Matthew B. and A. Michael Huberman. 1989. Qualitatif Data Analysis: A Sourcebook of New Method. USA: Ninth Printing.

Mutiah, Diana. 2012. Psikologi Bermain Anak Usia Dini. Jakarta: Kencana Prenada.

Pamadhi, Hadjar. 2009. Pendidikan Seni di SD. Jakarta: Universitas Terbuka.

Paspiani, Ni Kadek Nelly. 2015. Kegiatan Latihan Gerak dan Lagu (Jeruk Bali) Untuk Meningkatkan Perkembangan Motorik Kasar Pada Anak Usia Dini. Jurnal $\begin{array}{llll}\text { Pendidikan Anak, } & \text { Vol } & 4 & \text { No.1. }\end{array}$ https://journal.uny.ac.id/index.php/jpa/article/view/12340 diakses 13 Juni 2017 Pukul 09.18 WIB.

Pekerti, Widia. 2013. Metode Pengembangan Seni. Jakarta: Universitas Terbuka.

Tilaar, H.A.R. 2004. Paradigma Baru Pendidikan Nasional. Jakarta: Rineka Cipta.

Undang-Undang Nomor 20 Tahun 2003 tentang Sistem Pendidikan Nasional.

Yetty, Elindra., \& Siti Kurniasih. 2015. Play Dance Creation Efforts In Enhancing The Intelligence Interpersonal Early Childhood. Proceeding of The International Seminar On Languages and Art (ISLA)-4. Faculty of Language and Arts: Universitas Negeri Padang. 